\title{
Detection of Illicit Substances in Slimming Products Available in UAE
}

\author{
Ebtisam AR Alabdooli ${ }^{1}$, Preetha J Shetty ${ }^{2 *}$, Victor RM Chandrasekaran ${ }^{2}$ and Anoop KA ${ }^{3}$ \\ ${ }^{1}$ Head of Toxicology, General Department of Forensic Science and Criminology, Dubai, UAE \\ ${ }^{2}$ Assistant Professor, College of Medicine, Gulf Medical University, Ajman, UAE \\ ${ }^{3}$ Professor, College of Medicine, Gulf Medical University, Ajman, UAE
}

${ }^{*}$ Corresponding author: Preetha J Shetty, Assistant Professor, College of Medicine, Gulf Medical University, Ajman, UAE, E-mail: preethajshetty@yahoo.com

Citation: Ebtisam AR Alabdooli, Preetha J Shetty, Victor RM Chandrasekaran, Anoop KA (2017) Detection of Illicit Substances in Slimming Products Available in UAE. J Nutr Health Sci 4(1): 103. doi: 10.15744/23939060.4.103

\section{Received Date: December 29, 2016 Accepted Date: April 22, 2017 Published Date: May 18, 2017}

\begin{abstract}
Slimming products have gained popularity due to its easy availability and quick source to curb obesity. Studies suggest that they often contain banned compounds which produce adverse effects on repeated use. The objective of the present study was to estimate the concentration of illicit substances, sibutramine and phenolphthalein, in the slimming products of different origin which are commonly marketed in UAE using Gas Chromatography-Mass Spectroscopy (GC-MS).

The study revealed that $60 \%$ samples contained sibutramine and /or phenolphthalein. The slimming products from Germany and France contained only phenolphthalein, whereas products from USA, Thailand, Italy and England showed the presence of both and the highest concentrations were found in samples from China $(2846 \pm 455 \mu \mathrm{g} / \mathrm{g} ; 27 \pm 4.2 \mathrm{ng} / \mathrm{g})$. The slimming products from Iran, Lebanon and Morocco were not only free from these adulterants but also less expensive indicating that the high cost does not guarantee the safety of these products.
\end{abstract}

Keywords: Slimming products, Sibutramine, Phenolphthalein

\section{Introduction}

In seeking easier options for weight control, obese people are increasingly resorting to 'quick-fix' slimming agents available over the counter. These products are often advertised to contain purely natural ingredients, hence assumed to be harmless. However, many such products have been reported to contain various illicit agents, including sibutramine, diethylpropion, phenolphthalein, fenfluramine, $\mathrm{N}$-nitroso-fenfluramine, phentermine phenytoin, and even animal thyroid tissue posing a health risk on prolonged usage [1-6]. One study reported that the presence sibutramine and phenolphthalein resulted in high mortality and morbidity in Hong Kong population [4]. Several products have been withdrawn following detection of these adulterants, but many escape as structural analogues are difficult to detect.

Sibutramine, a 'serotonin-noradrenaline re-uptake inhibitor' gives a satiety feeling after a small meal, reducing their food intake $[7,8]$. Despite several central and peripheral side effects it is used alongside diet and exercise by obese patients resulting in life threatening complications [9-12]. Phenolphthalein on repeated use damages the intestinal mucosa and liver, causes serious psychiatric problems and also produces carcinogenic effect due to estrogenic and clastogenic properties, hence banned [13-15].

The study intended to estimate the concentration of two banned compounds, phenolphthalein and sibutramine, in slimming products from different countries available locally using Gas chromatography (Thermo Scientific, USA) coupled with mass spectrometry (TRACE DSQ) being one of the sensitive techniques that can detect these compounds even at very low concentrations.

Moreover, it compares the cost and quality of various slimming products based on the presence of adulterants detected in various samples. To the best of our knowledge, this is the first study undertaken in UAE for estimation of adulterants and cost comparison.

\section{Materials and Methods}

\section{Sample}

Slimming products from 10 different countries (three brands from two different batches) were obtained ( $\mathrm{n}=60)$ from the local market and analyzed in duplicate using GC-MS. The samples from each country were also classified as herbal (22) and non-herbal 
(38) depending on their origin.

\section{Chemicals and reagents}

Sibutramine stock $(1 \mathrm{mg} / \mathrm{ml})$ and phenolphthalein powder (HPLC grade) and Codeine-d3 were purchased from Sigma-Aldrich (St. Louis, MO). N-methyl-N-trimethylsilyl-trifluoroacetamide (MSTFA), trimethylchlorosilane (TMCS) were purchased from Fluka (Buchs, Switzerland).

\section{Sample preparation}

Samples (0.3g) were extracted using Toxi tube A \& B (Agilent technologies, Santa Clara, CA). $50 \mu \mathrm{L}$ of internal standard codeine-d3 was added and centrifuged at $3800 \mathrm{rpm}$ for $3 \mathrm{~min}$. The supernatant was transferred to glass tube for drying under nitrogen system. $500 \mu \mathrm{L}$ of ethyl acetate solvent was added for dilution and $100 \mu \mathrm{L}$ was mixed with $50 \mu \mathrm{L}$ of MSTFA in GC/MS vial and $2 \mu \mathrm{L}$ was used for analysis.

\section{Analytical conditions}

Fused silica capillary column (30 m X $0.25 \mathrm{~mm}$; Inner Diameter (ID)) bonded with $0.25 \mu \mathrm{m}$ Dura Bond 5 - Mass Spectrophotometry (DB5-MS; Agilent technologies, Santa Clara, CA) was used as a stationary phase. The analytical conditions were: sample volume 2 $\mu \mathrm{L}$; injector temperature $280^{\circ} \mathrm{C}$; septum purge flow $3 \mathrm{~mL} / \mathrm{min}$; Purge flow to split vent $50 \mathrm{~mL} / \mathrm{min}$; initial oven temperature $70^{\circ} \mathrm{C}$ and increased to $280^{\circ} \mathrm{C}$ at a rate of $12^{\circ} \mathrm{C} / \mathrm{min}$ held for $11 \mathrm{~min}$. Ionization was achieved by a $70 \mathrm{eV}$ electron beam at a current of $2.0 \mathrm{~mA}$. The concentrations of sibutramine and phenolphthalein in the samples were calculated from the masses and retention time. The correlation coefficient for sibutramine and phenolphthalein are 0.997 (Figure 1a and 1b) and 0.996 (Figure 2a and 2b). All estimated values were presented as mean \pm Standard Deviation (SD). The concentration of sibutramine and phenolphthalein was compared between herbal and non-herbal products using student's ' $\mathrm{t}$ ' unpaired test $(\mathrm{p}<0.05)$ and also with cost per gram of sample.

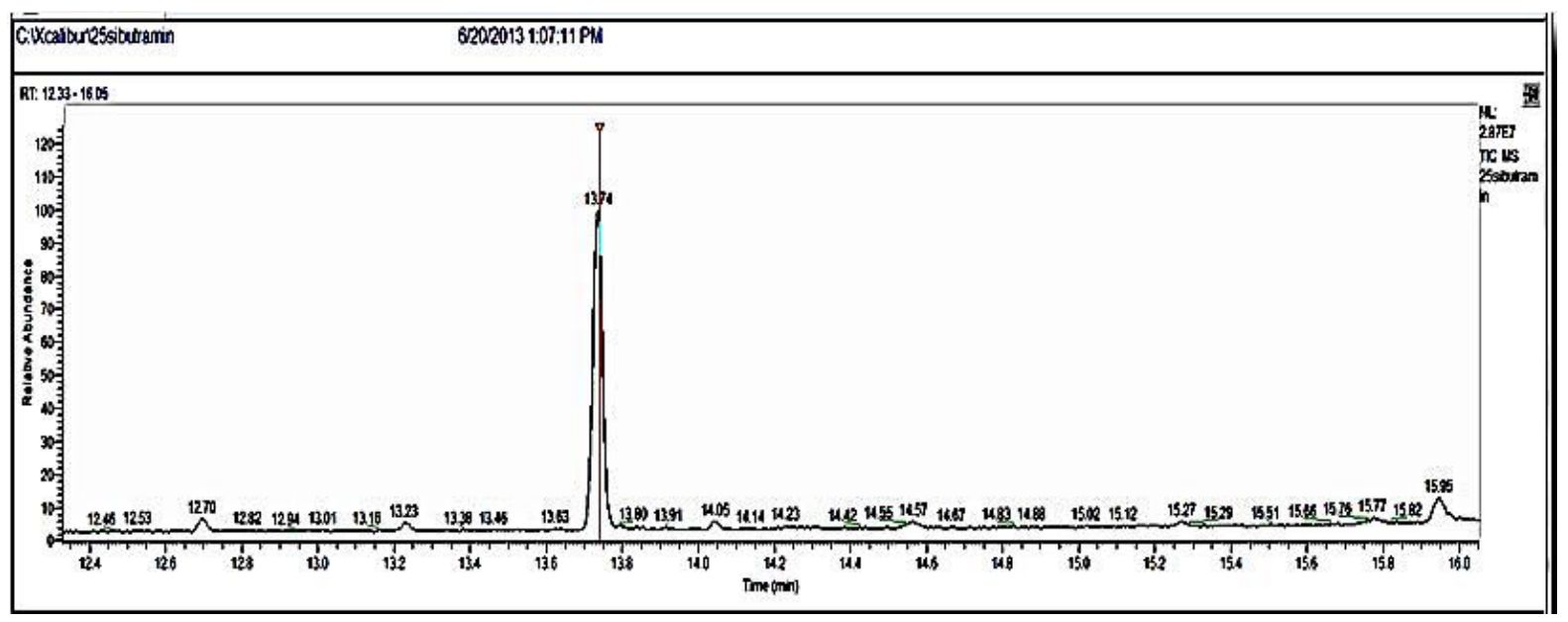

Figure 1a: Spectrum of sibutramine at retention time $13.74 \mathrm{~min}$

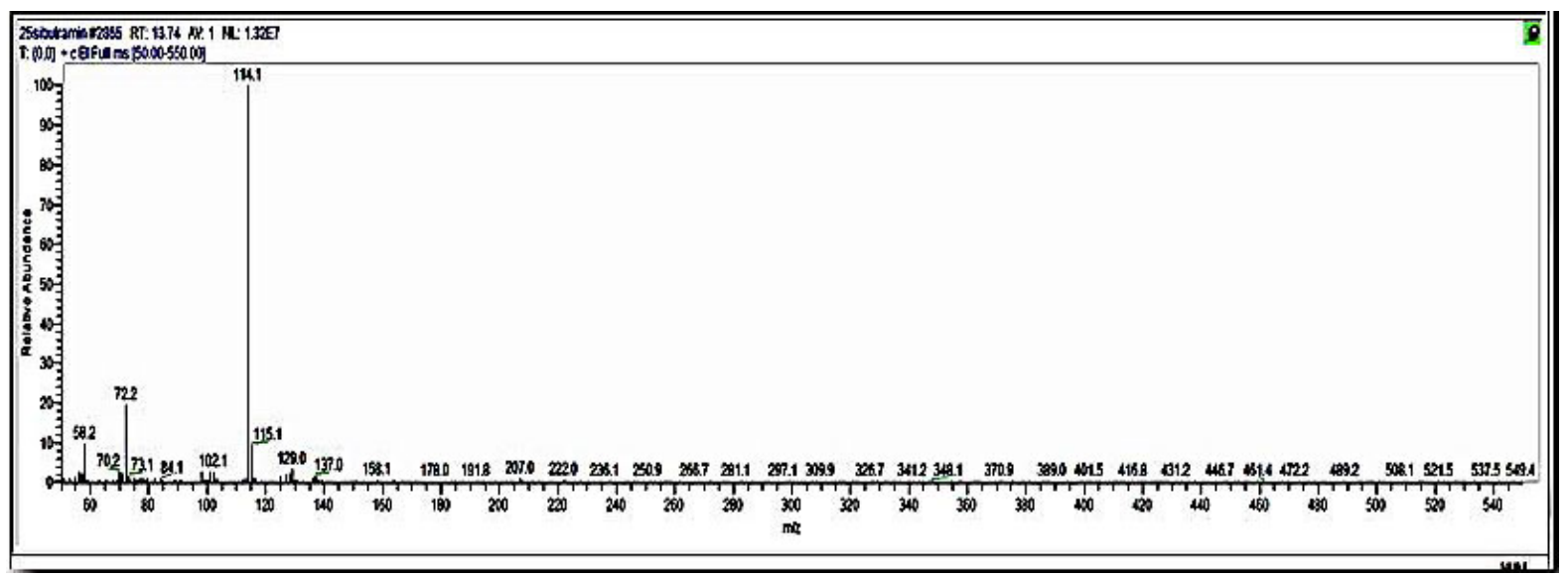

Figure 1b: Fragmented mass of sibutramine $72 \mathrm{~m} / \mathrm{z}$ and $114 \mathrm{~m} / \mathrm{z}$ 


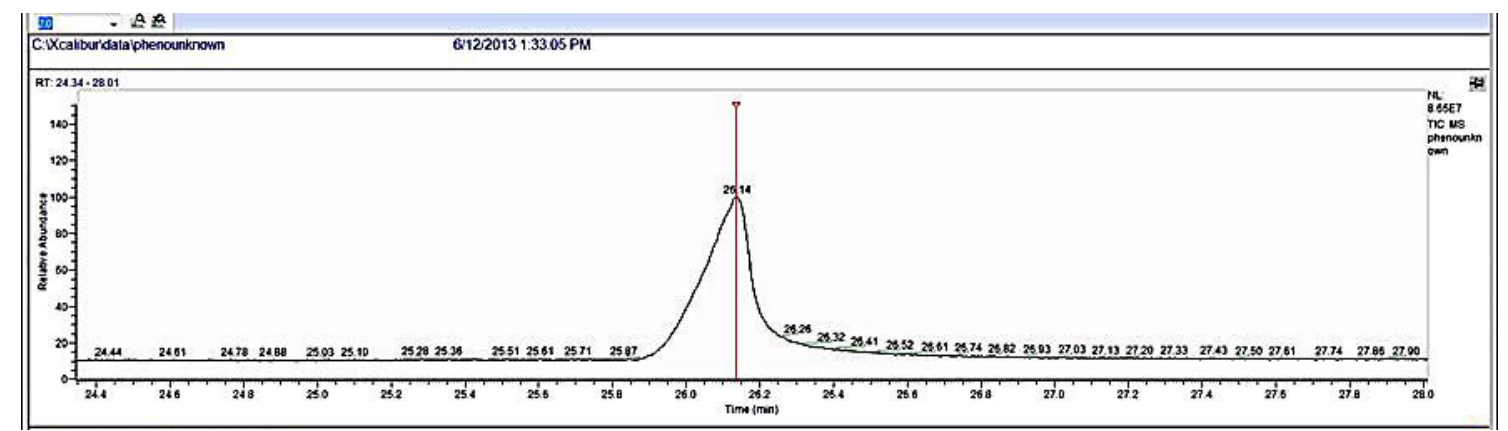

Figure 2a: Spectrum of phenolphthalein at retention time $26.14 \mathrm{~min}$

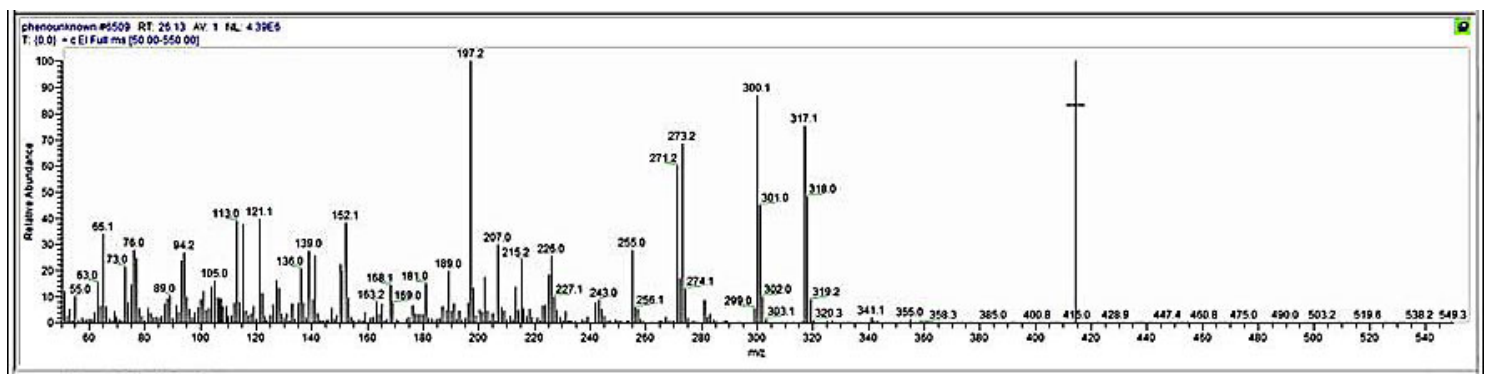

Figure 2b: Fragmented mass of phenolphthalein $225 \mathrm{~m} / \mathrm{z}, 274 \mathrm{~m} / \mathrm{z}$ and $318 \mathrm{~m} / \mathrm{z}$

\section{Results}

The results revealed that $60 \%$ of the samples contained sibutramine and /or phenolphthalein. $33 \%$ of the samples were adulterated with sibutramine and phenolphthalein. Products from China had highest concentration of both sibutramine $(2846 \pm 455 \mu \mathrm{g} / \mathrm{g})$ and phenolphthalein $(27 \pm 4.2 \mathrm{ng} / \mathrm{g})$ as compared to USA, Thailand, Italy and England (Table 1). Products from Germany and France which constituted $27 \%$ of the total samples contained only phenolphthalein. There was no significant difference in the concentration of sibutramine and phenolphthalein in herbal (1699 $\pm 606 \mu \mathrm{g} / \mathrm{g} ; 15 \pm 1.5 \mathrm{ng} / \mathrm{g})$ and non-herbal (1977 $\pm 836 \mu \mathrm{g} / \mathrm{g}$; $16 \pm 6.4 \mathrm{ng} / \mathrm{g}$ ) (Data not shown) slimming products irrespective of the country of origin. All Products from Morocco, Lebanon and Iran were free from these adulterants. The mean costs per gram of sample from different countries versus sibutramine and phenolphthalein concentration were presented in Table 1.

\begin{tabular}{|c|c|c|c|}
\hline Country & $\begin{array}{c}\text { Cost } \\
(\mathrm{AED} / \mathrm{g})\end{array}$ & $\begin{array}{c}\text { Sibutramine concentration } \\
(\boldsymbol{\mu g} / \mathbf{g})\end{array}$ & $\begin{array}{c}\text { Phenolphthalein concentration } \\
(\mathbf{n g} / \mathrm{g})\end{array}$ \\
\hline USA $^{*}$ & 31 & $1320 \pm 439$ & $12.4 \pm 4.1$ \\
\hline China & 15 & $2846 \pm 455$ & $24 \pm 4.2$ \\
\hline Thailand & 15 & $1928 \pm 71$ & $27 \pm 1.4$ \\
\hline Italy & 13 & $1657 \pm 510$ & $16.8 \pm 2.8$ \\
\hline England & 11 & $2023 \pm 994$ & $13.8 \pm 1.39$ \\
\hline France & 7.7 & ND & $12.9 \pm 1.19$ \\
\hline Germany & 6.5 & ND & $14.4 \pm 2.4$ \\
\hline Morocco & 6 & ND & ND \\
\hline Lebanon & 5 & ND & ND \\
\hline Iran & & ND & ND \\
\hline
\end{tabular}

"The most expensive slimming product; " The cheapest slimming product; ND - Nondetectable

The permissible limit for sibutramine by FDA is $15 \mathrm{mg} /$ day and use of phenolphthalein is completely banned.

Table 1: Cost of slimming product and concentration of sibutramine \& phenolphthalein in samples from different countries.

\section{Discussion}

Slimming products have gained wide popularity in the recent past as obesity has reached epidemic proportions and is a major contributor to the global burden of chronic disease and disability [16-19]. In the present study, 60\% slimming products were found to contain with sibutramine and/or phenolphthalein although they have been banned by the Food and Drug Administration (FDA). A study conducted in Hong Kong reported that the presence of these illicit chemicals resulted in high mortality and morbidity [4]. Another study on the slimming products also showed the presence of sibutramine in high concentrations (2400 $\mu \mathrm{g} / \mathrm{g}$ ) comparable to our study where the highest concentration of sibutramine was also estimated to be $2846 \mu \mathrm{g} / \mathrm{g}$. Sibutramine 
being a serotonin reuptake inhibitor increases the level of serotonin in the brain causing early satiety, thus reducing the food intake [20]. Adding phenolphthalein possibly helps to reduce the dose of sibutramine and its associated side effects without altering the weight-loss effects of the product. However, high dose or repeated use leads to cardiovascular adverse effects such as increased blood pressure, tachycardia, palpitations, and seizures [21]. Thus, subjects with a history of hypertension, coronary artery disease, congestive heart failure, arrhythmias, bleeding disorders etc. tend to run a high risk. In the present study, phenolphthalein was found in several slimming products from different countries though it has been withdrawn even as a laxative due to potential carcinogen. Animal studies showed that phenolphthalein induced neoplasia in the ovary, atypical hyperplasia, hematopoietic cell proliferation, toxicity to the kidney and reproductive system in mice [22,23]. However, earlier studies also reported the presence of phenolphthalein as an adulterant in several illicit weight-loss supplements $[24,25]$. Both these compounds have been regarded unsafe in slimming products as their adverse effects outweigh their desired benefits [26]. The addition of sibutramine and phenolphthalein in the slimming products tend to increase their efficacy, thereby increasing the brand value and price. However, the low priced products analyzed were devoid of these adulterants and pose a lower health risk to the consumers on repeated use (Table 1). It is recommended that all slimming products available in the market should be screened for FDA listed banned substances thus protecting against the ill effects of popular 'quick-fix' remedies to lose weight.

\section{Conclusion}

The study revealed that the expensive slimming products from seven different countries contained sibutramine and/or phenolphthalein which have been banned by FDA due to risk of serious heart events. Interestingly, the less expensive products from Iran, Lebanon and Morocco were free from above adulterants. The high cost does not guarantee the safety of these products.

\section{Acknowledgement}

We would like to acknowledge Mr. Sagar Thapa for his assistance in the Toxicology Laboratory, GMU, Ajman (UAE).

\section{References}

1. Mathon C, Ankli A, Reich E, Bieri S, Christen P (2014) Screening and determination of sibutramine in adulterated herbal slimming supplements by HPTLC-UV densitometry. Food Addit Contam Part A Chem Anal Control Expo Risk Assess 31: 15-20.

2. Vanherweghem JL, Depierreux M, Tielemans C, Abramowicz D, Dratwa M, et al. (1993) Rapidly progressive interstitial renal fibrosis in young women: association with slimming regimen including Chinese herbs. Lancet 341: 387-91.

3. Muller D, Weinmann W, Hermanns-Clausen M (2009) Chinese Slimming Capsules Containing Sibutramine Sold Over the Internet. Dtsch Arztebl Int 106: 218-22.

4. Tang MHY, Chen SPL, Ng SW, Chan AYW, Mak TWL (2011) Case series on a diversity of illicit weight-reducing agents: from the well-known to the unexpected. Br J Clin Pharmacol 71: 250-3

5. Dunnick JK and Hailey JR (1996) Phenolphthalein Exposure Causes Multiple Carcinogenic Effects in Experimental Model Systems. Cancer Res 56: 4922-6.

6. Dara L, Hewet J, Lim JK (2008) Hydroxycut hepatotoxicity: A case series and review of liver toxicity from herbal weight loss supplements. World J Gastroenterol 14: 6999-7004.

7. Clark DW and Harrison-Woolrych M (2004) Sibutramine may be associated with memory impairment. BMJ 329: 1316.

8. Bodhankar SL, Thakurdesai P, Singhal S, Gaur V (2007) Anorexic effect of (R)-Sibutramine: comparison with (R)-sibutramine and (S)-Sibutramine. Indian J Physiol Pharmacol 51: 175-8.

9. Cheung BMY, Cheung TT, Samaranayake NR (2013) Safety of Antiobesity Drugs. Ther Adv in Drug Safe 4: 171-81.

10. Daglioglu N and Akcan R (2012) Sibutramine detected in Chinese herbal drug. Nobel Med 8: 100-2.

11. Phattanawasin P, Uthai S, Tasamaporn S, Jariya A, Sarunyaporn K (2012) Quantitative Determination of Sibutramine in Adulterated Herbal Slimming Formulations by TLC-Image Analysis Method. Forensic Sci Int 219: 96-100.

12. Chen SP, Tang MH, Ng SW, Poon WT, Chan AY, et al. (2010) Psychosis associated with usage of herbal slimming products adulterated with sibutramine: a case series. Clin Toxicol 48: 832-8.

13. Slovacek L, SlovacKova B, Pavlik V, Slanska I (2009) Sibutramine- its impact on health-related quality of life and depression among adult obese non diabetic patient. Bratisl Lek Listy 110: 496-9.

14. Cooper GS, Longnecker MP, Sandler DP, Ness RB (2000) Risk of ovarian cancer in relation to use of phenolphthalein-containing laxatives. Br J Cancer 83: 404-6.

15. Cooper GS, Longnecker MP, Peters RK (2004) Ovarian cancer risk and use of phenolphthalein-containing laxatives. Pharmacoepidemiol Drug Saf 13: 35-9.

16. Nasreddine L, Naja F, Chamieh MC, Adra N, Sibai AM, et al. (2012) Trends in overweight and obesity in Lebanon:evidence from two national cross-sectional surveys (1997 and 2009). BMC Public Health 12: 798-809.

17. Ruesten AV, Steffen A, Floegel A, van der DL, Masala G et al. (2011) Trend in Obesity Prevalence in European Adult Cohort Populations during Follow-up since 1996 and their Predictions to 2015. PLoS One 6: e27455.

18. Murphy EL, Schlumpf K, Wright DJ, Cable R, Roback J et al. ( 2012) BMI and obesity in US blood donors: a potential public health role for the blood centre. Public Health Nutr 15: 964-71.

19. Verduin P, Agarwal S, Waltman S (2005) Solutions to obesity: perspectives from the food industry. Am J Clin Nutr 82(suppl): 259S-61S.

20. Hayun, Maggadani BP, Amalina N (2016) Determination of sibutramine adulterated in herbal Slimming products using tlc densitometric method. Indonesian J Pharm 27: 15-21.

21. Kang JG and Park CY (2012) Anti-Obesity Drugs: A Review about Their Effects and Safety. Diabetes Metab J $36: 13-25$.

22. Racette SB, Deusinger SS, Deusinger RH (2003) Obesity: Overview of Prevalence, Etiology, and Treatment. Phys Ther 83: $276-288$. 
23. Vorona RD, Winn MP, Babineau TW, Eng BP, Feldman HR, et al. (2005) Overweight and Obese Patients in a Primary Care Population report less sleep than patients with a normal body mass index. Arch Intern Med 165(1): 25-30.

24. Johansson M, Fransson D, Rundlof T, Huynh N, et al. (2014) A general analytical platform and strategy in search for illegal drugs. Journal of Pharmaceutical and Biomedical Analysis 100: 215-229.

25. Khazan M, Hedayati M, Kobarfard F, Askari S, Azizi F (2014) Identification and determination of synthetic pharmaceuticals as adulterants in eight common herbal weight loss supplements. Iranian Red Crescent Medical Journal 16: e15344.

26. Garg M, Hooda M, Solanki J, Saini S, Das S et al. (2011) A Recent Update on Undeclared Chemicals in Herbal Formulations. JPBMS 9.

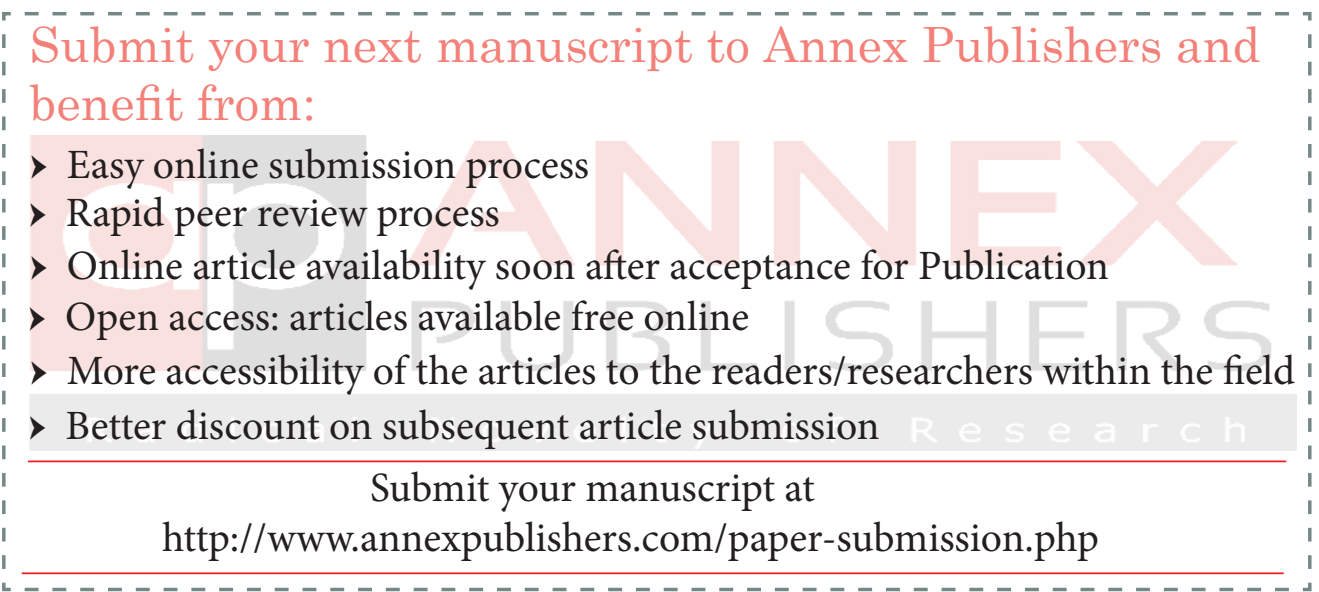

